\title{
Duplication of Effort across Development Projects in Nigeria: An Example Using the Master Health Facility List
}

\section{Olusesan Ayodeji Makinde, 1,2,3, Emmanuel C. Meribole ${ }^{4}$, Kolawole Azeez Oyediran ${ }^{5}$, Fadeke A. Fadeyibi $^{4}$, Marc Cunningham ${ }^{5}$, Yetunde Hussein-Fajugbagbe ${ }^{4}$, Femi Toye $^{4}$, Akin Oyemakinde ${ }^{4}$, Stephanie Mullen ${ }^{5}$}

1. MEASURE Evaluation, JSI, Abuja, Nigeria.

2. Viable Knowledge Masters, Abuja, Nigeria.

3. Demography and Population Studies Program, Schools of Public Health and Social Sciences, University of the Witwatersrand, Johannesburg, South Africa.

4. Department of Health Planning, Research and Statistics, Federal Ministry of Health, Abuja, Nigeria.

5. MEASURE Evaluation, JSI, Arlington, VA, USA 22209.

\begin{abstract}
Objective: Duplication of effort across development projects is often the resultant effect of poor donor coordination in low- and middle-income countries which receive development assistance. This paper examines the persistence of duplication through a case study of health facility listing exercises in Nigeria.

Methods: Document reviews, key informant interviews, and a stakeholder's meeting were undertaken to identify similar health facility listing exercises between 2010 and 2016.

Results: As an outcome of this process, ten different health facility listing efforts were identified.

Discussions: Proper coordination and collaboration could have resulted in a single list grown over time, ensuring return on investments. This study provides evidence of the persistence of duplication, years after global commitment to harmonization, better coordination and efficient use of development assistance were agreed to.

Conclusions: The paper concludes by making a proposal for strategic leadership in the health sector and the need to leverage information and communications technology through the development of an electronic Health Facility Registry that can archive the data on health facilities, create opportunity for continuous updates of the list, and provide for easy sharing of the data across different country stakeholders thereby eliminating duplication.

Keywords: Aid Effectiveness, Donor coordination; Health Facilities; Health Information System; Health Systems; International Cooperation; Master Facility List

Correspondence: sesmak@gmail.com
\end{abstract}


DOI: 10.5210/ojphi.v10i2.9104

Copyright @2018 the author(s)

This is an Open Access article. Authors own copyright of their articles appearing in the Online Journal of Public Health Informatics. Readers may copy articles without permission of the copyright owner(s), as long as the author and OJPHI are acknowledged in the copy and the copy is used for educational, not-for-profit purposes.

\section{Introduction}

Donors commit significant resources to supporting the health systems of several low- and middle-income countries (LMICs). Between 1992 and 2006, donor funding for health and population nearly quadrupled, reaching US\$13.6 billion annually [1]. Relative annual contribution of external aid as a share of total health spending rose from $15.3 \%$ to $29.4 \%$ between 2001 and 2011 in low-income countries. Also, external aid per capita increased by 25\% per year from US\$1.8 to US\$6.1 for the same period [2]. Development projects are often poorly coordinated across different donors resulting in duplication of effort and a waste of resources [3].

Duplication of effort occurs when more than one project or intervention is needlessly implementing similar activities within a geographic location or country which arises often because of poor knowledge management and inadequate coordination of projects, thereby resulting in aid inefficiency [4]. While duplication of effort has been recognized as a challenge to international cooperation projects with strategies aimed at addressing them such as through direct budgetary support to governments (sector-wide approach) rather than financing through projects which often gave room for the duplication, several development interventions are still structured in the project model [5,6]. Corruption, lack of transparency, and donor resistance to change are important factors that have limited the adoption of the sector-wide approach by donors [6]. In Rwanda, improved donor coordination resulted in wide ranging successes which include: less duplication of effort, reduction in the number of parallel systems of accounting, procurement, and management, and reduction in the number of inappropriately designed and coordinated projects among other benefits [7]. However, this was achieved through the sector-wide approach and after gaining the confidence of donors through transparent processes [7].

Realizing the wastage as a result of weak coordination, collaboration and partnerships, several global initiatives have been launched to foster harmonization, enhance coordination, promote leveraging of resources and forge the development of a joint agenda to address these problems. Some of these global initiatives include: the High Level Forum on Harmonization in Rome (2003), the Marrakech Roundtable on Managing for Results (2004), the Paris Declaration on Aid Effectiveness (2005), the Accra Agenda for Action (2008) and the Busan Partnership for Effective Development Cooperation (2011) [8,9]. The Paris Declaration on Aid Effectiveness was developed on five mutually reinforcing principles: ownership, alignment, harmonization, managing for results and mutual accountability [8].

The importance of donor and partner coordination was less talked about as a means of achieving better development goals and the reduction of wastage of resources in LMICs. However, recent observations suggest that donor coordination is as important as the amount of resources that are 
being committed to development. Increased commitment of donor resources has not been shown to have a similar effect on the level of development in recipient countries [10-12]. This is a challenge for both donors and recipient countries as investments are not yielding the desired returns and development outcomes.

While donor coordination is an important factor, it requires a government institutional framework through a national coordinating agency with technical capacity to be in the driver's seat and to liaise with donors for the effort to be meaningful. Though the Paris Declaration gave responsibility for coordination to both the donor and recipient countries, the largest responsibility rests on recipient countries to make the best use of aid [8]. Notwithstanding, there are documented instances of donors withholding fund availability information from recipient country institutions thereby challenging an appropriate planning mechanism [6,9,13].

In Nigeria, the responsibility for donor coordination lies with the Ministry of Budget and National Planning, which was until recently known as the National Planning Commission. For the health sector, donor funded projects are expected to coordinate with and support the Federal Ministry of Health (FMOH), which is responsible for implementing the national government's plan on health. However, coordination by and between these in-country institutions is still suboptimal. As part of strategies aimed at addressing donor coordination in the Nigerian health sector, different interventions have been put in place such as the development of the National Strategic Health Development Plan (NSHDP): 2010-2015 and a rationalization exercise to allocate donors to specific geographic areas [14]. The NSHDP proposed the establishment of a Health Development Partners Forum which provides an opportunity for donors and the government to coordinate interventions. The NSHDP further identified the need for the establishment of better funding mechanisms using the sector wide approach.

This paper investigates the persistence of duplication on development projects in Nigeria through a case study focusing on the creation of health facility lists. Health facility lists are important planning tools for determining the capacity of services available in a country and the equity in distribution of the services among the population $[15,16]$. According to the World Health organization, a Master Health Facility List (MFL) "is a complete listing of health facilities in a country (both public and private) and is comprised of a set of identification items for each facility (signature domain) and basic information on the service capacity of each facility (service domain)" [17]. A MFL is also an important source for delineating registered and/or licensed from unregistered/ unlicensed health facilities in the country. Information on the location and services provided by health facilities is important as Nigeria begins to implement its plan for achieving Universal Health Coverage (UHC) by 2030 [18]. One important objective of UHC is equity in access to services by the population which can be determined through the information available in the MFL [19]. An up-to-date MFL will also serve as the source of the statistics of the expected routine encounter reports from active health facilities in a country. One major challenge that has been reported in the management of the national health management information system is the difficulty with determining the statuses of the health facilities over time as some close out and new health facilities emerge [20]. This affects the ease of computation of the number of active health facilities that serve as the denominator statistic when calculating completion and reporting rates for the routine health information system. Thus, the unavailability of an up-todate MFL in a country has several direct and indirect consequences on the health system. 
The list of health facilities in a country infrequently changes thereby making the study of parallel efforts to develop health facility lists across the country a good case study to highlight duplication of effort.

\section{Methods}

This study was carried out as part of a large project intervention to strengthen the national health information system in Nigeria. A mixed-methods approach was adopted to collect the data to address the objectives of the study. A review of available government reports and strategic documents, key informant interviews (KIIs) and a stakeholder's workshop was carried out to [1] identify the health facility lists that were created since 2010 [2], understand the rationale for the creation of the various lists [3], learn about the breadth of the data collection that was done to create the lists [4] determine the availability of the health facility lists and the data they contain and [5] learn how the data was used since the creation of the lists. Table 1 describes the research methods used and information sources consulted.

\section{Document Review}

The documents reviewed were identified through prior knowledge of the health facility listing projects by the researchers, searching the internet for any documents on health facility listing in Nigeria using terms such as "Health Facility Lists" AND "Nigeria" in Google Search and from information retrieved from key informants. Openly accessible documents were downloaded from the websites of the organizations that carried out the exercises and additional documents were retrieved through formal request for the reports from the projects.

\section{Key Informant Interviews}

Key informants were interviewed to help identify additional health facility listing exercises that had taken place in the country, the rationale for the exercises, use of the information collected and the availability of the data. First, the government institutions that had carried out the health facility listing exercises or collaborated with a development partner were identified and approached. Then, key informants who had played a major role during the health facility listing exercise carried out were identified and interviewed. During the interview, we investigated about the health facility listing exercise wanting to know the rationale, the number of health facilities covered, which donor was involved, and how the data had been used since the creation of the list. We also retrieved any reports where available.

Table 1: Sources of Information

\begin{tabular}{|c|c|}
\hline Research Method & Information Source \\
\hline \multirow[t]{3}{*}{ Document Review } & - Directory of Health Facilities in Nigeria [21], \\
\hline & $\begin{array}{l}\text { - Publication describing the Master Health Facility List in Nigeria } \\
\text { [22], }\end{array}$ \\
\hline & $\begin{array}{l}\text { - Report and conference presentation of the Strengthening Health } \\
\text { Outcomes through the Private Sector (SHOPS) project private } \\
\text { health facility census [26,27], }\end{array}$ \\
\hline
\end{tabular}




\begin{tabular}{|c|c|}
\hline & $\begin{array}{l}\text { - Website reporting the project implemented by the Office of the } \\
\text { Senior Special Assistant to the President of Nigeria on the } \\
\text { Millennium Development Goals in collaboration with } \\
\text { Columbia University [23] } \\
\text { - Presentation on service availability mapping for HIV in Nigeria } \\
\text { at Nigeria Health and Mapping summit and a Poster at the } 19^{\text {th }} \\
\text { International AIDS Society conference [28,29] } \\
\text { - Conference presentation on Malaria Diagnostic Service } \\
\text { Availability-Mapping of Private Sector Service Delivery } \\
\text { Outlets in } 7 \text { PMI/MAPS Supported States, Nigeria [30] } \\
\text { - Reports of the GIS Mapping of Primary Healthcare Facilities in } \\
\text { Nigeria [31] } \\
\text { - Report of the Mapping Exercise of Reproductive, Maternal, } \\
\text { Newborn, Child and Adolescent Health in Nigeria [32] }\end{array}$ \\
\hline $\begin{array}{l}\text { Key Informant Interview } \\
\text { Agencies/organizations }\end{array}$ & $\begin{array}{l}\text { - Department of Health Planning, Research and Statistics } \\
\text { - National Agency for the Control of AIDS } \\
\text { - National AIDS and STIs Control Programme } \\
\text { - National Primary Healthcare Development Agency }\end{array}$ \\
\hline Stakeholder’s Workshop & $\begin{array}{l}\text { - Government officers across different departments and agencies } \\
\text { including all those that had done some health facility listing } \\
\text { exercise, donors (including those that have funded the } \\
\text { activities identified), implementing partners, bilateral and } \\
\text { multilateral agencies, health facility regulatory authorities. }\end{array}$ \\
\hline
\end{tabular}

\section{Stakeholder's Workshop}

The stakeholder's workshop was convened by the Department of Health Planning Research and Statistics of the FMOH and was held August 30-31, 2016 in Abuja, Nigeria. The meeting was convened with the funding support of the United States Agency for International Development (USAID) and technical assistance from MEASURE Evaluation. There were over 50 participants at the workshop and they cut across government departments and agencies, donor organizations, bilateral and multilateral agencies and local and international implementing partners. Representatives of each government organization/ department that had carried out a health facility listing exercise were invited to make presentations on their projects. A generic Microsoft PowerPoint template of the expectations of each effort was developed to reinforce the information needed and in addition aid uniformity of presentations at the workshop. It included (i) the name of the organization/ project, (ii) year of the health facility list data collection, (iii) partner/ donor that supported the effort, (iv) purpose/ objective of the exercise, (v) types of health facilities covered, (vi) states covered, (vii) availability of the data, (viii) use of the data since creation and (ix) the total number of health facilities listed. 
The presentations were delivered by government personnel from the various units that had carried out the exercises. Members of the audience were then permitted to field questions on the presentations made. Notes were taken by the lead author and the presentations delivered by each participant was also retrieved and analyzed. In addition, the group broke out into sessions to discuss the presentations and to jointly identify issues with the different efforts and the most suitable way forward in addressing the duplication. At plenary, the outcomes of the discussions were made by the team members.

As an outcome of the stakeholder's workshop, a Technical Working Group (TWG) was set up to lead the agreed interventions. Members of the TWG cut across the different technical departments and agencies of the Federal Ministry of Health, one state level Ministry of Health, some donors, and bilateral and multilateral agencies. The goal of the TWG was to help determine the minimum dataset on health facilities that would satisfy all the stakeholders and to identify best practices for managing health facility lists in order to avoid duplication. While this TWG was given the immediate assignment to help in determining a minimum dataset for the MFL, the TWG subsequently agreed on the need for the development of an electronic Health Facility Registry (HFR) as the best means for managing the MFL data.

\section{Results}

Six independent government departments/ agencies were found to have partnered with different development organizations between 2010 and 2016 to create a total of 10 health facility and service availability lists across Nigeria (Table 2). Some of these efforts covered a few states or specific diseases. It is noteworthy that government institutions led each of the exercises except two (the Strengthening Health Outcomes through the Private Sector (SHOPS) Project - Census of Private Health Facilities which was conducted as research to determine the level of correctness of the government lists on private health facilities in the six states where the censuses were carried out and the Malaria Consortium/ DFID risk mapping exercise). The health facilities covered by the lists were hospitals and clinics predominantly. Only the service availability mapping exercise carried out by the National AIDS and STIs Control Programme in 2011/2012 included one other class of health facility beside hospitals and clinics.

The directory of the health facilities published by the Federal Ministry of Health in 2013 was identified as the federal government's approved list of health facilities [21]. However, it had several shortcomings. Only hospitals and clinics had been listed during its development, few parameters mainly on each health facility excluding global positioning system (GPS) coordinates was collected and it lacked processes and an information system to manage the list and keep it updated [20]. The data collected during the exercise include: the name of the facility, state, local government area, ward of location, the ownership (private or public), level of care (primary, secondary or tertiary) and a unique identifier which was allotted to each facility through this effort. The process for completing this directory has been documented by the Federal Ministry of Health [22].

The effort led by the Office of the Senior Special Assistant to the President on the Millennium Development Goals was also reviewed [23]. The information collected by the project included geographic coordinates of health facilities and services available at the facilities. Other data collected by the project were for other social infrastructure such as schools and water facilities 
within each community. However, the website (http://nmis.mdgs.gov.ng/) which once displayed interactive maps of the health facilities and other infrastructure is no longer available. An effort to locate the office for formal interviews did not yield results, as the project was no longer active.

For six of the 10 efforts identified, the service information collected on the health facilities was specific to disease programs such as: malaria, HIV/AIDS and reproductive, maternal, newborn, child, adolescent health and nutrition programs. Based on information provided by key informants, it was discovered that GPS devices were procured more than once for the specific purpose of collection of GPS coordinate data by the different projects which was wasteful as GPS coordinates do not change. If properly archived and shared after collection, the GPS coordinates for health facilities could have served more than one project's goal. Furthermore, the cost of logistics towards the completion of the individual data collection efforts across the large geographic area which Nigeria covers would have been quite significant based on projections from other efforts supported by MEASURE Evaluation. Figure 1 shows the number of events that have taken place in each state across the country while Figure 2 shows the states involved in each of the 10 exercises.

\section{Discussion}

In the absence of an up-to-date MFL in Nigeria, several projects embarked on the establishment of project-specific health facility lists in order to satisfy their project goals. These projects were occasionally across a few states and narrowly focused. Yet, some were across the entire country. Though the identified projects in Table 2 were carried out for specific purposes, our study reveals that improper coordination of the activities of the different government departments and agencies led to a waste of resources and brewed inefficiency. Using the available resources to strengthen the national MFL could have helped to enrich the effort previously completed in the country by the Department of Health Planning, Research and Statistics of the FMOH (the custodians of health data for the country) further while also meeting the individual project goals. Such efforts would have helped in growing the MFL and to expand the data elements as well as to establish processes and procedures for the continuous updating of the health facility list.

In the next sections of the paper, we discuss our observed points of duplication and its attendant consequences. We further present strategies for addressing duplication including strategic leadership and the deployment of an electronic Health Facility Registry (HFR) for managing the MFL as a potential intervention for addressing the duplication and improving the efficiency of the health facility listing efforts in the country.

\section{Points of Duplication in Health Facility Listing Efforts}

Though it is well documented that aid fragmentation and poor coordination deters aid effectiveness in recipient countries, evidence continues to show that donor commitment to better coordination are yet to be achieved [3,9,24]. Our analysis of the health facility listing projects revealed that duplication of effort persists in Nigeria. 
Table 2: Findings from the health facility lists assessment exercise

\begin{tabular}{|c|c|c|c|c|c|c|c|}
\hline $\begin{array}{l}\text { Nigerian Government } \\
\text { Agency/ Department/ } \\
\text { Project }\end{array}$ & $\begin{array}{l}\text { Year of } \\
\text { Activity }\end{array}$ & $\begin{array}{l}\text { Number } \\
\text { of Health } \\
\text { facilities } \\
\text { listed }\end{array}$ & Coverage & Rationale & $\begin{array}{l}\text { GPS } \\
\text { Coordin } \\
\text { ates } \\
\text { Collecte } \\
\text { d }\end{array}$ & Data Use & Funding Agency \\
\hline $\begin{array}{l}\text { Department of Health } \\
\text { Planning, Research and } \\
\text { Statistics, Federal Ministry } \\
\text { of Health (DHPRS) }\end{array}$ & 2011 & 34,423 & Nationwide & $\begin{array}{l}\text { A national master } \\
\text { health facility list } \\
\text { that allocates unique } \\
\text { identifiers to all } \\
\text { health facilities in } \\
\text { the country }\end{array}$ & No & $\begin{array}{l}\text { For planning. } \\
\text { Recognized as } \\
\text { the national } \\
\text { health facility } \\
\text { list. }\end{array}$ & $\begin{array}{l}\text { Federal Government of } \\
\text { Nigeria and USAID } \\
\text { (MEASURE Evaluation) }\end{array}$ \\
\hline $\begin{array}{l}\text { National AIDS and STIs } \\
\text { Control Programme (HIV/ } \\
\text { AIDS Division), } \\
\text { Department of Public } \\
\text { Health, Federal Ministry of } \\
\text { Health/ National Agency for } \\
\text { the Control of AIDS } \\
\text { (NASCP) }\end{array}$ & $\begin{array}{l}2011 / \\
2012\end{array}$ & $24,473^{1}$ & 32 States & $\begin{array}{l}\text { A HIV service } \\
\text { availability mapping } \\
\text { across } 32 \text { states in } \\
\text { the country. }\end{array}$ & Yes & $\begin{array}{l}\text { Two conference } \\
\text { presentations. }\end{array}$ & $\begin{array}{l}\text { USAID (Health Systems } \\
\text { 20/20)/ Global Fund }\end{array}$ \\
\hline $\begin{array}{l}\text { National Primary } \\
\text { Healthcare Development } \\
\text { Agency (NPHCDA) }\end{array}$ & $\begin{array}{l}2011 / \\
2012\end{array}$ & 7,889 & 9 States & $\begin{array}{l}\text { Mapping of all } \\
\text { public primary } \\
\text { healthcare facilities } \\
\text { across priority } \\
\text { states. }\end{array}$ & Yes & Planning. & $\begin{array}{l}\text { Federal Government of } \\
\text { Nigeria }\end{array}$ \\
\hline $\begin{array}{l}\text { Office of the Senior Special } \\
\text { Assistant to the President of } \\
\text { Nigeria on the Millennium } \\
\text { Development Goals (OSSA } \\
\text { MDG) }\end{array}$ & $\begin{array}{l}2011- \\
2014\end{array}$ & 34,116 & Nationwide & $\begin{array}{l}\text { Service availability } \\
\text { mapping across the } \\
\text { country. }\end{array}$ & Yes & $\begin{array}{l}\text { Interactive } \\
\text { website that is } \\
\text { no longer } \\
\text { available. }\end{array}$ & $\begin{array}{l}\text { Conditional Grants Scheme } \\
\text { Program, Federal } \\
\text { Government of Nigeria }\end{array}$ \\
\hline $\begin{array}{l}\text { SHOPS Project - Census of } \\
\text { Private Health Facilities } \\
\text { across Six States }^{2} \text { (SHOPS) }\end{array}$ & $\begin{array}{l}2012 / 20 \\
13\end{array}$ & 5,086 & 6 States & $\begin{array}{l}\text { Research project to } \\
\text { validate government } \\
\text { lists of private health } \\
\text { facilities and } \\
\text { establish baseline } \\
\text { for engagement on a }\end{array}$ & Yes & $\begin{array}{l}\text { Research on } \\
\text { assessing } \\
\text { completeness of } \\
\text { state health } \\
\text { facility lists. } \\
\text { Report and }\end{array}$ & USAID (SHOPS) \\
\hline
\end{tabular}

Online Journal of Public Health Informatics * ISSN 1947-2579* http://ojphi.org * 10(2):e208, 2018 


\begin{tabular}{|c|c|c|c|c|c|c|c|}
\hline & & & & USAID project. & & $\begin{array}{l}\text { conference } \\
\text { presentation }\end{array}$ & \\
\hline $\begin{array}{l}\text { Malaria } \\
\text { Consortium/KEMRI/ } \\
\text { University of Oxford }\end{array}$ & 2014 & 20,817 & Nationwide & $\begin{array}{l}\text { Malaria risk } \\
\text { mapping in public } \\
\text { primary and } \\
\text { secondary health } \\
\text { facilities listed in the } \\
\text { National District } \\
\text { Health Information } \\
\text { System Platform }\end{array}$ & Yes & Project planning & DFID \\
\hline $\begin{array}{l}\text { National Malaria } \\
\text { Elimination Program, } \\
\text { Department of Public } \\
\text { Health, Federal Ministry of } \\
\text { Health (NMEP) }\end{array}$ & 2014 & 900 & 12 states & $\begin{array}{l}\text { Health facility } \\
\text { assessment to } \\
\text { determine } \\
\text { availability and } \\
\text { quality of services } \\
\text { offered for malaria. }\end{array}$ & Yes & $\begin{array}{l}\text { Project } \\
\text { planning, } \\
\text { conference } \\
\text { presentation }\end{array}$ & Global Fund \\
\hline $\begin{array}{l}\text { National Malaria } \\
\text { Elimination Program, } \\
\text { Department of Public } \\
\text { Health, Federal Ministry of } \\
\text { Health (NMEP) }\end{array}$ & 2015 & 1,430 & 9 states & $\begin{array}{l}\text { Health facility } \\
\text { assessment to } \\
\text { determine } \\
\text { availability and } \\
\text { quality of services } \\
\text { offered for malaria. }\end{array}$ & Yes & $\begin{array}{l}\text { Research, } \\
\text { conference } \\
\text { presentation }\end{array}$ & World Bank \\
\hline $\begin{array}{l}\text { National Primary } \\
\text { Healthcare Development } \\
\text { Agency/ UNFPA }\end{array}$ & 2015 & 6,063 & 9 states & $\begin{array}{l}\text { Mapping of } \\
\text { reproductive, } \\
\text { maternal, newborn, } \\
\text { child and adolescent } \\
\text { health in public and } \\
\text { private health } \\
\text { facilities across nine } \\
\text { states. }\end{array}$ & Yes & Project planning & UNFPA \\
\hline $\begin{array}{l}\text { National Agency for the } \\
\text { Control of AIDS (NACA) }\end{array}$ & 2016 & 5,351 & 6 States & $\begin{array}{l}\text { Service availability } \\
\text { mapping across the } \\
\text { country (suspended } \\
\text { by donor midway) }\end{array}$ & Yes & Project Planning & Global Fund \\
\hline
\end{tabular}


Figure 1: Number of times health facility lists were generated by states

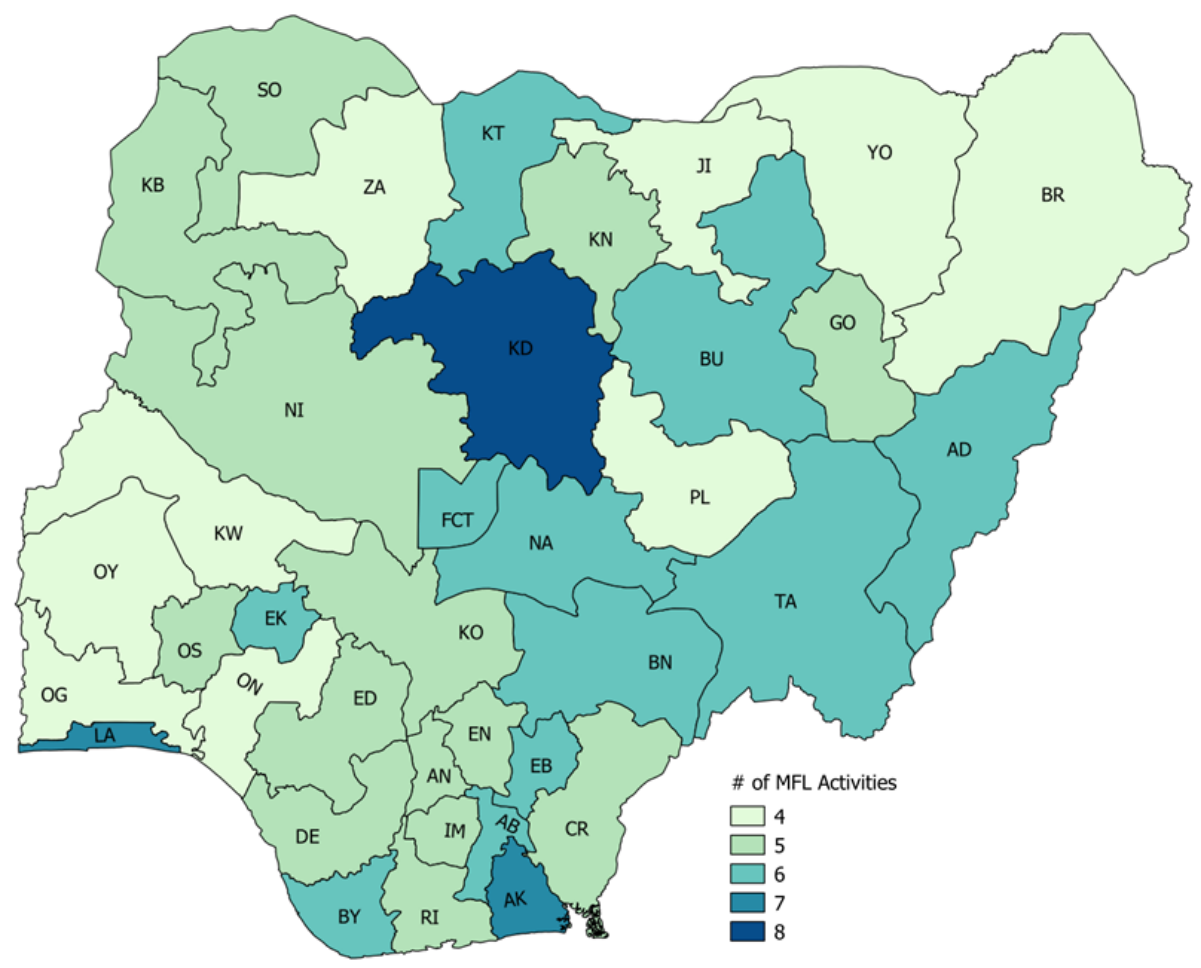

Figure 2: States covered by each of the identified exercises
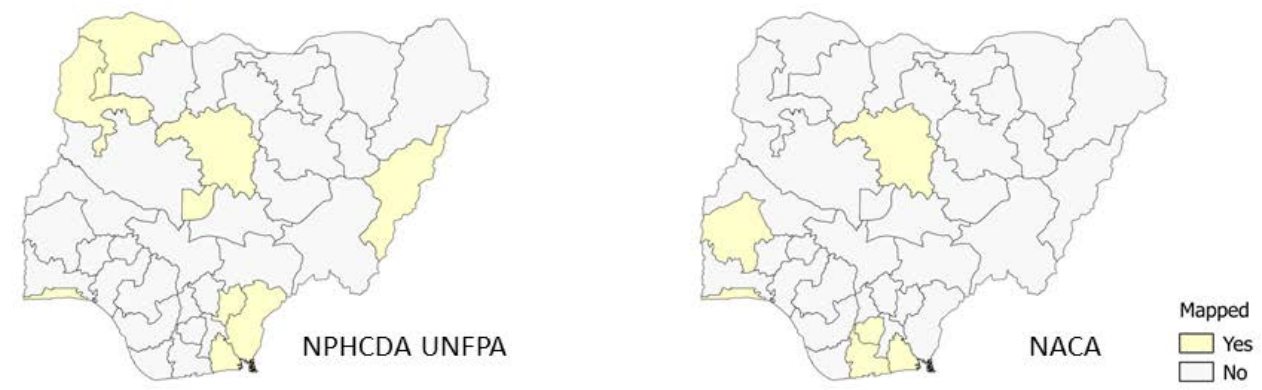

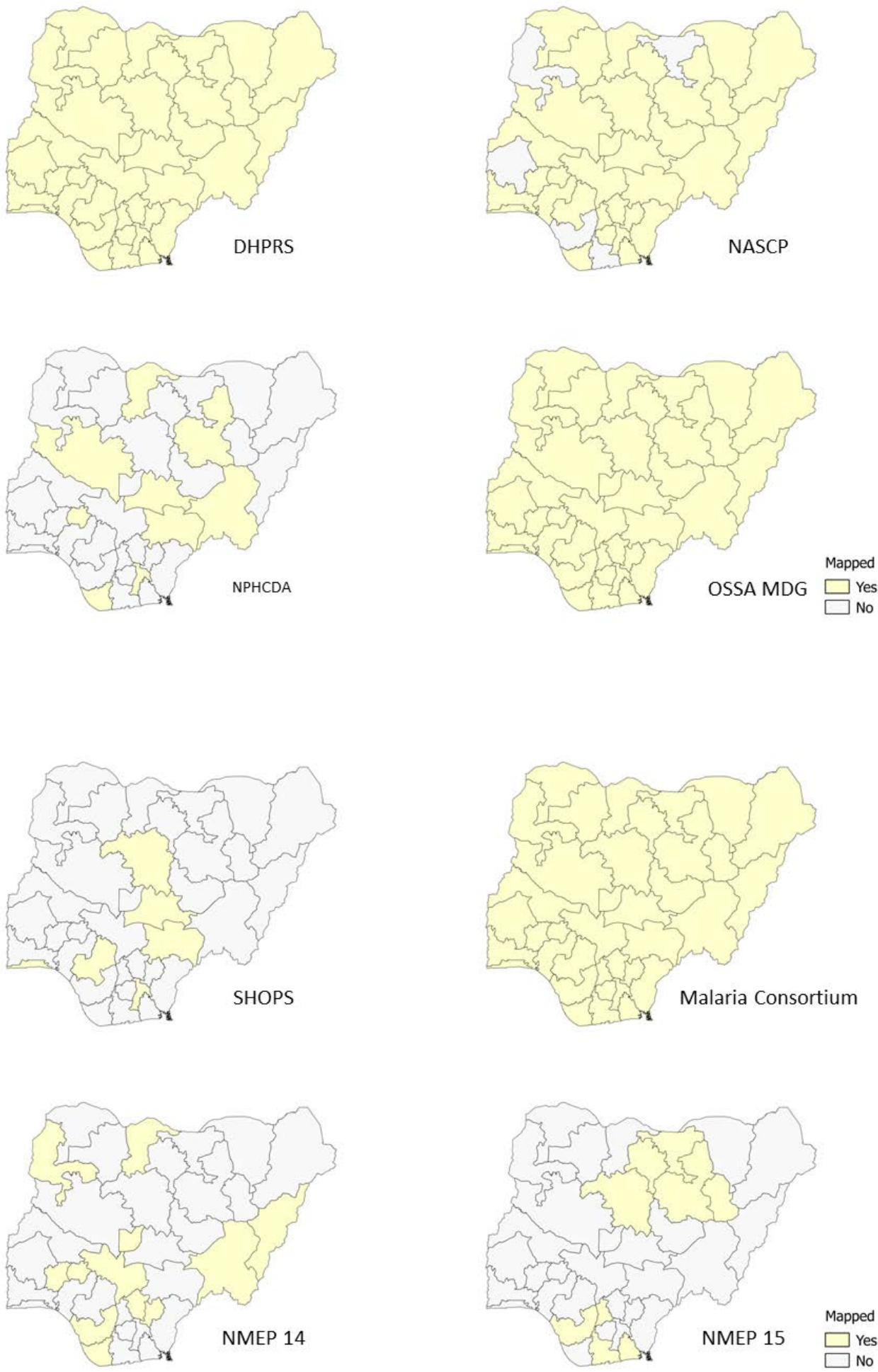
Several health facility listing efforts were clustered between 2010 and 2012, often funded by international aid with the aim of collecting health facility data that often overlapped with prior completed efforts. This was also about the time that the FMOH had updated its national MFL and had highlighted the need for expansion and strengthening of this list through the development of an information system to manage the records [21,22]. The different projects identified often collected data on the name of the facility, address, level of care, ownership, contact information, the GPS coordinates and other specific parameters for that health facility most of which could easily have been obtained from prior completed efforts.

The "bandwagon effect" cannot be ruled out as six different government departments within a relatively short time engaged in parallel health facility listing and mapping exercises across the country. The selling points to the projects were the visualizations and maps that could be generated from these relatively expensive data collection efforts. Though the projects often had disease specific objectives which justified the different interventions, one comprehensive data collection effort with an expanded scope for the different program areas could have sufficed. Several man-hours were spent collecting data that could have been more impactful if used in strengthening a single properly planned and coordinated effort. While the exact amount spent on each project was not available to the researchers, using estimates from the MEASURE Evaluation-supported effort to project costs reveal tens of millions of Naira have been expended in the parallel efforts.

\section{Consequences of Duplication of Health Facility Lists}

Duplication of effort results in a waste of limited resources. Despite significant investments, the health system in Nigeria is still challenged. Health indicators are poor with maternal mortality and infant mortality rates amongst the highest in the world [25].

Though the responsibility for maintaining such national data resource in Nigeria resides with the Department of Health Planning, Research and Statistics within the FMOH, different donor agencies funded alternate government institutions/ departments to carry out responsibilities that were not characteristically theirs. This was possible because the departments/ projects were operating in vertical systems and coordination within the Nigerian government was poor. Multiple health facility lists lead to confusion as every party acclaims that their controlled list is the most comprehensive and thus should be used for national decisions. Also, donor support towards multiple institutions in countries for similar work might empower the wrong department further disenabling the health system. Though often to obtain quick results, this eventually results in in-fighting and a long term fractured health system. Furthermore, the unattained health system goals could hamper future support as a result of donor fatigue. Consequently, the desired objectives of the health system are not met and the overall return on the investments is not achieved.

Also, the sustainability of narrowly focused parallel health facility listing efforts which may provide immediate results will eventually fail should the project funds dry up. This has been observed in the effort led by the Office of the Senior Special Assistant to the President on the Millennium Development Goals in partnership with Columbia University. The interactive website developed by the project that the authors once visited is no longer available online. Though a report on the project provided on the website of Columbia University stated that the 
project had been handed over to the team of the President's aide [23], this unit did not have the statutory responsibility to maintain such system. Funds to sustain the project beyond the grant would not have been allocated to that office thereby compromising ongoing maintenance of the website. As previously noted, the office has since been disbanded and there was no one to provide us official information on the project.

\section{Addressing Duplication in Health Facility Listing in Nigeria}

Addressing duplication in the health system as a whole will be a joint responsibility of the donors and the country governments. This should include better coordination of funding and decision making between both parties. Our two main suggestions for addressing the challenge of duplication with health facility listing are strategic leadership for the health system and by leveraging information and communications technology for sharing the MFL in an electronic HFR. The goal of the effort will be to eliminate duplication, improve efficiency in the use of aid while also helping the different stakeholders to achieve their individual project targets.

\section{Strategic Leadership}

Duplication of effort is a manifestation of a failure in the coordination of the health system. This is often possible because of poor responsibility assignment across the different health related agencies that exist at the national level in the country. Rather than work together, the institutions/ departments preferred to work in vertical projects and silos, which was inefficient and wasted resources. Despite the plan to move towards a sector-wide funding approach for development assistance as outlined by the NSHDP, this is still yet to be achieved as donor support is still being implemented in the vertical project pattern. The resulting manifestation is the persistence of duplication of projects. Identifying the reasons for the non-implementation of such strategies planned in the NSHDP: 2010-2015 and taking steps towards addressing them will be an important direction for the leadership of the health sector.

\section{The Health Facility Registry Model}

Leveraging information and communications technology in addressing the issue of health facility lists is another approach that has been proposed. A HFR can be deployed to archive the information on health facilities in Nigeria and thereby be used to share the data with interested parties based on appropriate governance principles. The HFR can also permit systems to pull data from it thereby allowing the government to maintain a single list of health facilities for the country and permitting other stakeholders to pull data from the system. A model for the HFR and how the data could be shared across different stakeholders is presented in Figure 3.

Figure 3: Health facility registry use demonstration 


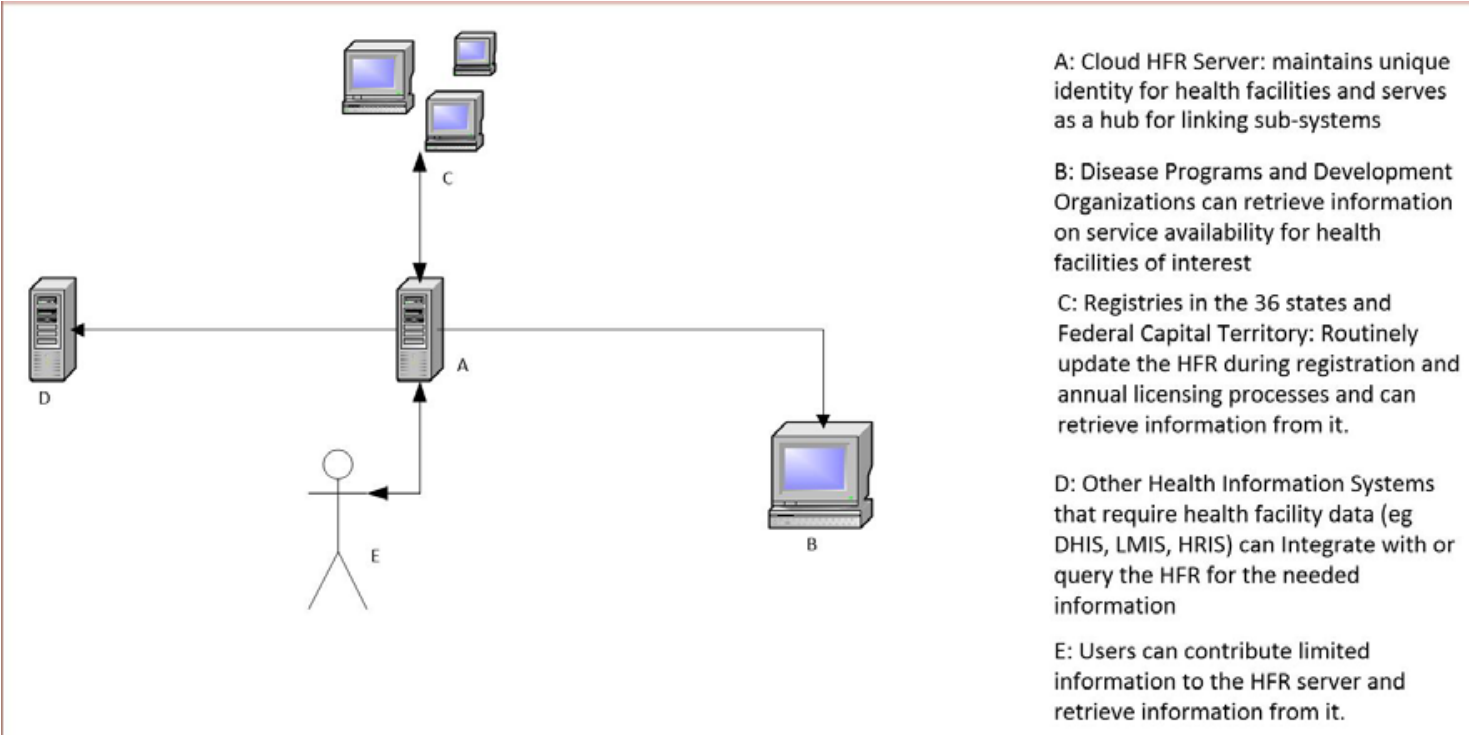

\section{Study Limitations}

The study is mainly qualitative and exploratory. Thus, many of the findings cannot be quantified. For instance, we could not obtain information on the cost of the different health facility listing efforts to determine the level of waste of resources by the parallel efforts. In addition, there may have been more health facility lists in circulation than reported, as we found additional projects on the internet after obtaining information from the stakeholders.

\section{Conclusion}

Our study provides evidence of how poor donor coordination and unclear national institution responsibilities result in aid inefficiency. Our proposed strategies for solving the identified problems are both internal (within the Nigerian government) and external (with the donors). The Federal Government needs to improve its in-house coordination, including streamlining of organizations with conflicting responsibilities to foster activities that will have the largest impact. It also needs to implement its plans such as the proposed sector wide approach of funding which was planned in the NSHDP: 2010-2015. In the interim, donors need to use discretion to identify the government departments with specific responsibilities for activities that they would like to support thereby fostering institutionalization. Supporting small components of national long-term goals rather than looking for quick wins will no doubt help recipient countries such as Nigeria achieve development targets better.

An information and communications technology-driven HFR as the harbor of the national MFL should be deployed for ongoing management of the records. The data on each health facility can be grown over time and thus respond to various vertical program interests. Nodes to access this robust database can then be shared with different government agencies and development partners 
that require such information for their various projects. This will help to eliminate the waste of resources by alternate service availability mapping exercises that are undertaken by different programs in Nigeria.

\section{Acknowledgments}

Financial support for this project was provided by the U.S. Agency for International Development (USAID) under the terms of MEASURE Evaluation cooperative agreement AIDOAA-L-14-00004. Views expressed are not necessarily those of USAID or the United States government. We acknowledge the contributions of Mr. Oladipo Adegbotolu and Mr. Olutobi Adeogo during the course of project implementation.

\section{References}

1. Farag M, Nandakumar AK, Wallack SS, Gaumer G, Hodgkin D. 2009. Does Funding From Donors Displace Government Spending For Health In Developing Countries? Health Aff (Millwood). 28(4), 1045-55. PubMed https://doi.org/10.1377/hlthaff.28.4.1045

2. World Health Organization. WHO Global Health Expenditure Atlas [Internet]. Switzerland; 2014. 228 p. Available from: http://www.who.int/health-accounts/atlas2014.pdf

3. Aldasoro I, Nunnenkamp P, Thiele R. 2010. Less aid proliferation and more donor coordination? The wide gap between words and deeds. J Int Dev. 22(7), 920-40. https://doi.org/10.1002/jid.1645

4. Sullivan TM, Limaye RJ, Mitchell V, D’Adamo M, Baquet Z. 2015. Leveraging the Power of Knowledge Management to Transform Global Health and Development. Glob Health Sci Pract. 3(2), 150-62. PubMed https://doi.org/10.9745/GHSP-D-14-00228

5. Cassels A, Janovsky K. 1998. Better health in developing countries: are sector-wide approaches the way of the future? Lancet. 352(9142), 1777. PubMed https://doi.org/10.1016/S0140-6736(98)05350-1

6. Leiderer S. 2015. Donor Coordination for Effective Government Policies? J Int Dev. 27(8), 1422-45. https://doi.org/10.1002/jid.3184

7. Logie DE, Rowson M, Ndagije F. 2008. Innovations in Rwanda's health system: looking to the future. Lancet. 372(9634), 256-61. PubMed https://doi.org/10.1016/S0140$\underline{6736(08) 60962-9}$

8. OECD. Paris Declaration on Aid Effectiveness (2005) and the Accra Agenda for Action (2008) [Internet]. 2008. Available from: http://www.oecd.org/dac/effectiveness/34428351.pdf 
9. Lawson ML. 2011. Foreign aid: International donor coordination of development assistance. J Curr Issues Glob. 4(1), 77.

10. Dalil S, Newbrander W, Loevinsohn B, Naeem AJ, Griffin J, et al. 2014. Aid effectiveness in rebuilding the Afghan health system: A reflection. Glob Public Health. 9(Suppl 1), S12436. PubMed https://doi.org/10.1080/17441692.2014.918162

11. Kwamie A, Nabyonga-Orem J. 2016. Improved harmonisation from policy dialogue? Realist perspectives from Guinea and Chad. BMC Health Serv Res. 16(4), 222. PubMed https://doi.org/10.1186/s12913-016-1458-7

12. Rahman A, Sawada Y. 2012. Can donor coordination solve the aid proliferation problem? Econ Lett. 116(3), 609-12. https://doi.org/10.1016/j.econlet.2012.06.013

13. Ulikpan A, Narula I, Malik A, Hill P. 2014. "In the driver's seat": The Health Sector Strategic Master Plan as an instrument for aid coordination in Mongolia. Global Health. 10, 23. PubMed https://doi.org/10.1186/1744-8603-10-23

14. Federal Ministry of Health. National Strategic Health Development Plan (NSHDP) 2010 2015. Abuja, Nigeria; 2010.

15. Rose-Wood A, Heard N, Thermidor R, Chan J, Joseph F, et al. 2014. Development and use of a master health facility list: Haiti's experience during the 2010 earthquake response. Glob Health Sci Pract. •.•, ghs1400029.

16. Darcy N, Perera S, Stanley G, Rumisha S, Assenga K, et al. Case Study: The Tanzania Health Facility Registry. In: Health Information Systems and the Advancement of Medical Practice in Developing Countries [Internet]. 2017 [cited 2017 Mar 15]. p. 208-36. Available from: http://www.igi-global.com/chapter/case-study/178688

17. World Health Organization. Creating a Master Health Facility List [Internet]. 2012 [cited 2014 Jan 27]. Available from: http://www.who.int/healthinfo/systems/WHO_CreatingMFL_draft.pdf

18. Tilley-Gyado R, Filani O, Morhason-Bello I, Adewole IF. 2016. Strengthening the Primary Care Delivery System: A Catalytic Investment towards Achieving Universal Health Coverage in Nigeria. Health Syst Reform. 2(4), 277-84. https://doi.org/10.1080/23288604.2016.1234427

19. Makinde OA, Sule A, Ayankogbe O, Boone D. 2018. Distribution of Health Facilities in Nigeria: Implications and Options for Universal Health Coverage. Int J Health Plann Manage. PubMed https://doi.org/10.1002/hpm.2603

20. Makinde OA, Azeez A, Adebayo W. Potential use cases for the development of an electronic health facility registry in Nigeria: Key informant's perspectives. Online J Public Health Inform [Internet]. 2016 Sep [cited 2016 Sep 16];8(2). Available from: https://www.ncbi.nlm.nih.gov/pmc/articles/PMC5266756/. 
21. Federal Ministry of Health Nigeria. A directory of health facilities in Nigeria. Abuja, Nigeria: Federal Ministry of Health Nigeria; 2013.

22. Makinde OA, Azeez A, Bamidele S, Oyemakinde A, Oyediran KA, et al. 2014. Development of a Master Health Facility List in Nigeria [Internet]. Online J Public Health Inform. 6(2). http://www.ncbi.nlm.nih.gov/pmc/articles/PMC4235326/. PubMed https://doi.org/10.5210/ojphi.v6i2.5287

23. The Earth Institute. Columbia University. New Data Website Helps Nigeria's Campaign to Achieve Millennium Development Goals - The Earth Institute - Columbia University [Internet]. 2014 [cited 2016 Oct 13]. Available from: http://earth.columbia.edu/articles/view/3212

24. Nunnenkamp P, Öhler H, Thiele R. 2013. Donor coordination and specialization: did the Paris Declaration make a difference? Rev World Econ. 149(3), 537-63. https://doi.org/10.1007/s10290-013-0157-2

25. World Health Organization. World Health Statistics 2017: monitoring health for the SDGs, Sustainable Development Goals [Internet]. Geneva, Switzerland; 2017. Available from: http://apps.who.int/iris/bitstream/10665/255336/1/9789241565486-eng.pdf?ua=1

26. Johnson D, Woodman B, Toriola M, Kinnan C, Baruwa S. Assessing the role of private providers in Nigeria's health system. In New Orleans, USA; 2013. Available from: http://paa2013.princeton.edu/papers/132264

27. Woodman B, Baruwa S, Toriola M, Chatterji M, Kinnan C, et al. A Census of Private Health Facilities in Six States of Nigeria. 2014 [cited 2015 Jul 12]; Available from: http://africacapacityalliance.org/n4a/wp-content/uploads/2014/06/SHOPS-Nigeria-PrivateSector-Health-Census_6.15.2014-FINAL.pdf

28. Azeez A. Mapping HIV/ AIDS Services in Nigeria. In Abuja, Nigeria; 2011 [cited 2016 Oct 21]. Available from: https://www.measureevaluation.org/our-work/gis/nigeria-health-andmapping-summit-2011-resources/presentation-4

29. Katz I, Fadairo AF, Omeogu C, Azeez A. Geospatial mapping of quality measures of HIV services in Nigeria: Variations between states and services. In: Proceedings of the 19th International AIDS Society Conference [Internet]. Washington DC, USA; 2012 [cited 2016 Oct 21]. Available from: http://www.abtassociates.com/AbtAssociates/files/9a/9a88b717e639-4ae8-9f9a-745ccefa1e19.pdf

30. Ojo A, Aiyenigba B, Johnbull S, Onu A, Ipadeola O, et al. Malaria Diagnostic Service Availability-Mapping of Private Sector Service Delivery Outlets in 7 PMI/MAPS Supported States, Nigeria. In New Orleans, USA; 2014.

31. National Primary Healthcare Development Agency. Geographical Information System (GIS) Mapping of Primary Healthcare Facilities in Nigeria. Abuja, Nigeria; 2012. 
32. Adedeji O, Ojo W, Akinyemi A, Agunbiade O, Olaniran O. Mapping of Reproductive, Maternal, Newborn, Child and Adolescent Health in Nigeria. Abuja, Nigeria; 2015 Sep.

${ }^{1}$ Including few laboratories

${ }^{2}$ Identified during literature review and was not presented at the workshop 